\title{
Chloroperoxidase mediated oxidation of chlorinated phenols using electrogenerated hydrogen peroxide
}

\author{
Camilo E. La Rotta H.* \\ Enzyme Technology Laboratory \\ Institute of Chemistry \\ Federal University of Rio de Janeiro \\ UFRJ, CT, Bloco A Sala 539, Ilha do Fundão \\ CEP 21949-900, Rio de Janeiro, RJ, Brazil \\ Tel: 552125627359 \\ Fax: 552125627266 \\ E-mail: clarotta@iq.ufrj.br \\ Eliane D’Elia \\ Electrochemistry and Electroanalysis Laboratory \\ Institute of Chemistry \\ Federal University of Rio de Janeiro \\ UFRJ, CT, Bloco A Sala 634-A, Ilha do Fundão \\ CEP 21949-900, Rio de Janeiro, RJ, Brazil \\ E-mail: eliane@iq.ufrj.br \\ Elba P.S. Bon \\ Enzyme Technology Laboratory \\ Institute of Chemistry \\ Federal University of Rio de Janeiro \\ UFRJ, CT, Bloco A Sala 539, Ilha do Fundão \\ CEP 21949-900, Rio de Janeiro, RJ, Brazil \\ E-mail: elba1996@iq.ufrj.br
}

Financial support: This work has received financial support from the Brazilian Petroleum Agency (ANP) as a doctoral grant and from The Foundation for Research Support from the State of Rio de Janeiro - FAPERJ - Brazil.

Keywords: biodegradation, bioelectrochemistry, Caldariomyces fumago, chlorinated phenols, chloroperoxidase, hydrogen peroxide electrogeneration.

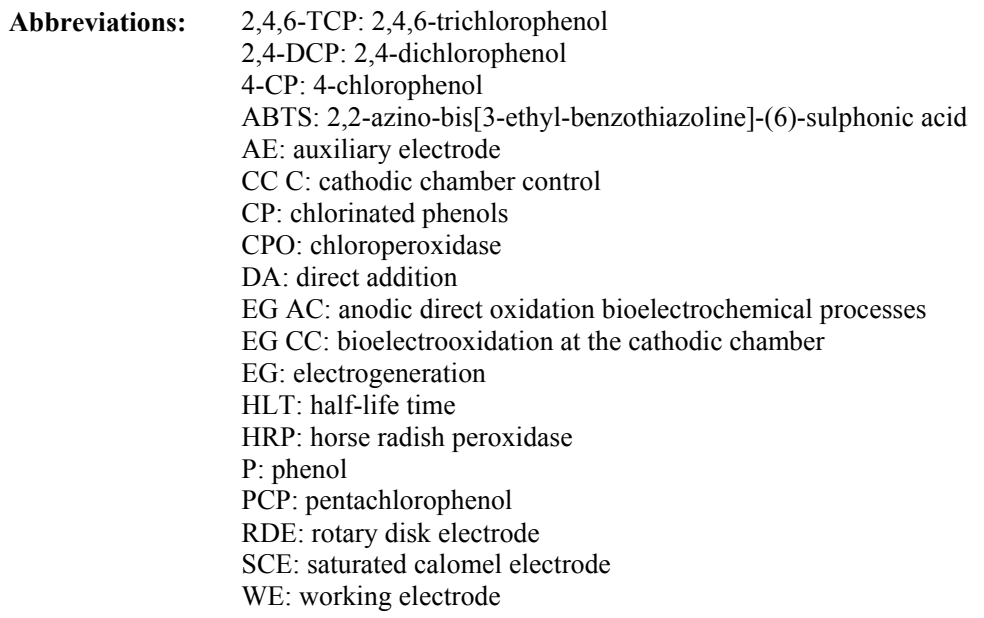

Chloroperoxidase (CPO) from Caldariomyces fumago catalyses the oxidation of several chlorinated phenols (CP) commonly found in industrial waste waters in the presence of hydrogen peroxide. This study compares the direct addition of hydrogen peroxide (DA) with its continuous electrogeneration (EG) during the enzymatic oxidation of CP. Reaction mixtures were studied containing chemically modified CPO, hydrogen peroxide and the phenolic substrates: phenol (P), 4chlorophenol (4-CP), 2,4-dichlorophenol (2,4-DCP),

*Corresponding author 


\section{2,4,6-trichlorophenol \\ $(2,4,6-$ TCP) \\ and pentachlorophenol (PCP), in $100 \mathrm{mM}$ sodium-potassium phosphate buffer $\mathrm{pH} 6.0$, at $25^{\circ} \mathrm{C}$. Results were compared in terms of residual phenol concentration (oxidation efficiency), precipitate formation (removal) and residual enzyme activity (stability). With the electrochemical system evaluated at $-620 \mathrm{mV}_{\text {SCE }}$, and continuous aeration the maximum $\mathrm{H}_{2} \mathrm{O}_{2}$ concentration of $1.2 \mathrm{mM}$ was obtained. Under this conditions and after $4 \mathrm{hrs}$ using EG, no phenol or 4-CP were detected, and $97 \%, 93 \%$ and $88 \%$ of $2,4-\mathrm{DCP}, 2,4,6-\mathrm{TCP}$ and PCP were degraded, respectively. The use of EG improves enzyme half-life time in comparison to the results obtained by DA.}

Non toxic phenols can result from plant degradation into tannin-like compounds which are responsible for flavour and colour of potable water and have natural occurrence in the environment. In contrast, phenolic compounds specially chlorinated phenols are unusual, being very toxic and caustic, for that reason they are considered highly pollutants (Atlow et al. 1984; Carmichael et al. 1985). These compounds are present in the wastewaters generated from industrial activities as such petrochemical, coalconversion, pharmaceutical, wood preserving, plastic, rubber proofing, pesticide use, iron steel and paper and cellulose bleaching. Large scale coal gasification and carbonization plants are also generators of wastewaters containing large quantities of high toxic phenolic compounds. The United States Environmental Protection Agency regulates the phenol content in the wastewater from less than $1 \mathrm{mg} / \mathrm{l}$ to the several thousand $\mathrm{mg} / \mathrm{l}$ (Denizli et al. 2004).

Conventional methods for phenol removal of industrial wastewater include chemical and photo oxidation, adsorption on activated charcoal, solvent extraction and microbial degradation (Atlow et al. 1984; Rivas et al. 1999). The application of these methods can be easily hindered by their cost, detoxification efficiency in relation to the phenol features and concentration as well as the formation of hazardous by-products. Furthermore, geographic and climate characteristics also affect the efficiency for wastewater treatment processes. This is particularly true concerning biological processes that are more sensible to the aforesaid factors.

Nowadays, environments in which contaminants are merely transferred from one medium to another are no longer acceptable. It is no surprising that biomolecules with oxidizing activity such as ozone or hydrogen peroxide should be so widely used. Both can act individually at high concentrations or in conventional biological treatments including as pre-treatment to degrade toxic, refractory or bio-inhibitory organics, make them more amenable to biodegradation. Hydrogen peroxide can be also used at low concentration in a polishing step with enzymatic reactions using peroxidases. In this approach, hydrogen peroxide can destroy trace levels of recalcitrant organics pollutants that could easily pass through biotreatments (Annachatre and Gheewala, 1996; Yee and Wood, 1997; Wagner and Nicell, 2002).

In the literature there are an extended list of works where the direct addition of hydrogen peroxide is combined with the enzymatic oxidation of phenol and other pollutants. Some of these examples are the biocatalytical oxidations achieved in the case of dyes as methylene blue (FerreiraLeitão et al. 2003) and phenolic compounds using horseradish peroxidase (HRP) (Nicell et al. 1993; Vasudevan and Li, 1996; Laurenti et al. 2003) or chloroperoxidase (CPO) (La Rotta and Bon, 2002). And in the oxidation of polyaromatic hydrocarbons (PAH's) using manganese peroxidase (Baborová et al. 2006; Eibes et al. 2006).

Nevertheless, the use of hydrogen peroxide in biocatalysis as co-substrate for peroxidase activity is limited due to its inhibitory effect at high concentrations above $25 \mathrm{mM}$ and slow deleterious effects at long time with lower concentrations (Nicell and Wright, 1997). One solution for this problem is the use of very low and controlled hydrogen peroxide supplementation, necessary just for the maintenance of an effective oxidation level, with no inhibitory effects. This can be achieved using direct pulsated addition (DA) or by in situ electrogeneration (EG). The electroenzymatic approach provides a significantly lower and easily controllable hydrogen peroxide formation rate than any other so far. EG was already applied to some biocatalytical oxidations, such as, in the asymmetric oxidation of thioanisole by CPO (Lütz et al. 2004), the oxidation of PCP (Kim and Moon, 2005), and the oxidation of dimethylaniline by HRP (Chen and Nobe, 1993).

The purpose of this study was to compare the conventional enzymatic degradation of phenolic compounds yet reported for HRP (Nicell at al. 1993) and CPO (La Rotta and Bon, 2002) with the electroenzymatic oxidation. Results were compared in terms of hydrogen peroxide production, electrochemical conditions, residual phenol concentration (oxidation efficiency), precipitate formation (removal efficiency), and residual enzyme activity after each treatment.

\section{MATERIALS AND METHODS}

\section{Biocatalyst features}

Chloroperoxidase (EC. 1.11.1.10) from Caldariomyces fumago CMI 89362 was produced, purified and chemically modified by cross linking with glutaraldehyde in accordance to previous reports (La Rotta and Bon, 2002; La Rotta et al. 2005). The enzyme concentration was given in $\mathrm{mmol} \cdot \mathrm{L}^{-1}$ from its extinction coefficient at $\mathrm{pH} 6.0\left(\mathrm{~A}_{403 \mathrm{~nm}}=\right.$ $75.3 \mathrm{mmol}^{-1} \cdot \mathrm{L} \mathrm{cm}^{-1}$ ) (Morris and Hager, 1966). Both initial and residual peroxidase activities were determined based on the oxidation of 2,2-azino-bis[3-ethyl-benzothiazoline]-(6)- 
sulphonic acid diamonium salt (ABTS) in the presence of hydrogen peroxide $100 \mathrm{mmol} \cdot \mathrm{L}^{-1}$ sodium-potassium phosphate $\mathrm{pH} 6.0$, at $25^{\circ} \mathrm{C}$. The change in absorbance was determined at $405 \mathrm{~nm}\left(\varepsilon_{405}=18600 \mathrm{~mol}^{-1} \cdot \mathrm{cm}^{-1}\right)$. One unit of peroxidase activity catalyses the oxidation of one $\mu$ moles per millilitres of ABTS per minute at $\mathrm{pH} 6.0$ and $25^{\circ} \mathrm{C}$ (Zhang and Nicell, 2000).

\section{Materials}

Phenol was purchased by Fluka Chemie GmbH (Buchs Switzerland); 4-chlorophenol, 2,4-dichlorophenol, 2,4,6trichlorophenol, 2,2'-azino-bis[3-ethyl-benzothiazoline-(6)sulphonic acid diamonium salt (ABTS), 4-aminoantipyrine (4-AAP) and Chitosan, medium molecular weight $85 \%$ DA were purchased from Sigma-Aldrich Co. (St. Louis - USA); Pentachlorophenol, potassium hexacyanoferrate (III) and $30 \%$ aqueous hydrogen peroxide solution were supplied by Merck Co. (Damnstag - Germany) this last one, was standardized by permanganometry. Graphite felt $(0.6 \mathrm{~mm}$ thickness) and reticulated vitreous carbon foam ( $3 \%$ density and 100 ppi) from Duocel - ERG Co. (Oakland - USA). Electrolytic copper web $\left(27 \mathrm{~cm}^{2}\right)$ from Haver \& Boecker (Westfalen - Germany).

\section{Equipment}

A spectrophotometer Shimadzu Multispect 1501 with temperature-controlled cell (Shimadzu Co. Japan) was used for the enzymatic and colorimetric assays. The electrochemical measurements during the hydrogen peroxide electrogeneration and bioelectrooxidation of $\mathrm{CP}$ were performed using a potentiostat/galvanostat Omnimetra PG 19 model (Brazil) and VoltaLab PGZ 301 Radiometer (Denmark) was using during the voltammetry studies.

\section{Voltammetry studies}

Voltammetry curves were obtained using as working electrode a rotary disk electrode (RDE) constituted by a cylindrical copper rod (Johnson - Maltey) with $0.2 \mathrm{~cm}^{2}$ of cross-sectional area, a scan rate of $150 \mathrm{mV} \cdot \mathrm{s}^{-1}$ was used and different disk speeds from 100 to $1000 \mathrm{rpm}$ were applied. The copper electrode surface was polished with a silicon carbide emery cloth grade 1000 , then rinsed with ethanol and finally dried under hot air. A platinum wire was used as auxiliary electrode (AE) and a saturated calomel electrode (SCE) as reference.

\section{Hydrogen peroxide electrogeneration}

The arrangement for the electrochemical bicompartmented reactor used in this study is presented in Figure 1. The electrochemical system was composed by a platinum wire as $\mathrm{AE}$ and saturated calomel electrode as reference. Graphite felt (GF) and reticulated vitreous carbon foam (RVCF), both with $2.0 \mathrm{~cm}^{2}$ of apparently surface area and an electrolytic copper web of $27 \mathrm{~cm}^{2}$ were evaluated as working electrodes (WE). Cathodic potentials from -120 to $-820 \mathrm{mV}$, were evaluated in terms of the hydrogen peroxide production as well as two strategies for air supplementation: Discontinuous aeration by 1 hour with pure $\mathrm{O}_{2}\left(5.0 \mathrm{~mL} \cdot \mathrm{min}^{-1}\right)$ and continuous aeration with pure $\mathrm{O}_{2}\left(5.0 \mathrm{~mL} \cdot \mathrm{min}^{-1}\right)$ along the $4 \mathrm{hrs}$ reaction. Continuous magnetic stirring at $200 \mathrm{rpm}$ was maintained in all cases. To evaluate $\mathrm{H}_{2} \mathrm{O}_{2}$ generation, samples during $4 \mathrm{hrs}$ from the cathodic chamber were taken, and then $\mathrm{H}_{2} \mathrm{O}_{2}$ was quantified using the methodology described bellow.

\section{Enzymatic oxidation of $\mathrm{CP}$ using direct addition (DA) and electrogeneration (EG) of $\mathrm{H}_{2} \mathrm{O}_{2}$}

DA experiments were evaluated using reaction mixtures containing $0.6 \mathrm{U} \cdot \mathrm{mL}^{-1}$ of $\mathrm{CPO} ; 0.5 \mathrm{mmol} \cdot \mathrm{L}^{-1}$ of the chlorinated phenol and 0.5 to $1.0 \mathrm{mmol} \cdot \mathrm{L}^{-1} \mathrm{H}_{2} \mathrm{O}_{2}$ at 100 $\mathrm{mmol} \cdot \mathrm{L}^{-1}$ potassium phosphate buffer $\mathrm{pH} \quad 6.025^{\circ} \mathrm{C}$ and magnetic stirring at $200 \mathrm{rpm}$. Reactions were started by single or step-wise addition of 3 and 5 equal pulses of hydrogen peroxide up-to the desired final hydrogen peroxide concentration. The bioelectrochemical oxidation of $\mathrm{CP}$ was performed using the reaction mixture described above. Reactions were started by the addition of CPO and turning on the system at a specific potential. Control experiments were also carried out where the effect of the anodic oxidation and the chemical oxidation due to hydrogen peroxide were determined.

\section{Hydrogen peroxide production and residual phenol quantifications}

A spectrophotometric method for microquantification of hydrogen peroxide was used, employing hydrogen peroxide reduction by a peroxidase followed by simultaneous oxidation of 2,4-dichlorophenol and coupling with 4aminoantipyrine. Reaction mixtures contained peroxidase (4.0 nmoles $\left.\cdot \mathrm{L}^{-1}\right)$, 2,4-dichlorophenol $\left(1.0 \mathrm{mmol} \cdot \mathrm{L}^{-1}\right)$ and 4 aminoantipyrine $\left(0.5 \mathrm{mmol} \cdot \mathrm{L}^{-1}\right)$ in $100 \mathrm{mmol} \cdot \mathrm{L}^{-1}$ potassium phosphate buffer $\mathrm{pH} 6.0$, at $30^{\circ} \mathrm{C}$. Variable concentrations of hydrogen peroxide were used as reaction starters. Absorbance readings were performed at $510 \mathrm{~nm}$ during three minutes and a pre-plotted in a calibration curve of hydrogen peroxide concentration $v s$. absorbance. The residual phenol quantification was performed using the modified red-phenol method (Metelitza et al. 1991; Fiamegos et al. 2002) based on the oxidation of the phenolic compound by potassium hexacyanoferrate (III), followed by simultaneous coupling with 4-aminoantipyrine in an alkaline 1:1 ethanol/water medium. Reaction mixtures of $2.0 \mathrm{~mL}$ containing $20 \mu \mathrm{L}$ of potassium hexacyanoferrate (III) (8\%), variable concentrations of CP from 0.05 to 1.0 $\mathrm{mmol} \cdot \mathrm{L}^{-1} 100 \mu \mathrm{L}$ of ammonium hydroxide $(2 \%)$ and $50 \mu \mathrm{L}$ of 4-aminoantipyrine $\left(40 \mathrm{mmol} \cdot \mathrm{L}^{-1}\right)$ were used to build the calibration curves of concentration $v s$. absorbance for each CP.

\section{CPO stability}

Residual peroxidase activity was determined from DA and EG experiments using reaction mixtures containing 0.6 
$\mathrm{U} \cdot \mathrm{mL}^{-1}$ of un-modified or cross-linked $\mathrm{CPO}, 0.5 \mathrm{mmol} \cdot \mathrm{L}^{-1}$ of 4-CP in $100 \mathrm{mmol} \cdot \mathrm{L}^{-1}$ sodium-potassium phosphate buffer $\mathrm{pH}$ 6.0. For DA a maximum hydrogen peroxide concentration of $1.0 \mathrm{mmol} \cdot \mathrm{L}^{-1}$ was assumed. Determination of the isolated effect of hydrogen peroxide as well as the effect of both phenol oxidized derivatives and hydrogen peroxide over the CPO activity were performed. Positive control for CPO activity contained only $0.6 \mathrm{U} \cdot \mathrm{mL}^{-1}$ of $\mathrm{CPO}$ in $100 \mathrm{mmol} \cdot \mathrm{L}^{-1}$ sodium-potassium phosphate buffer $\mathrm{pH}$ 6.0 in the absence of hydrogen peroxide and phenol. Similar negative control used a boiled CPO solution.

\section{RESULTS AND DISCUSSION}

\section{The hydrogen peroxide electrogeneration}

The electrochemical production of hydrogen peroxide results from the dissolved oxygen reduction present in the reaction mixture. This oxygen reduction produces, as final product, water, with the consumption of 4 electrons. However, depending on the material utilized as working electrode, this reaction could occur in two steps producing the stabilization of the hydrogen peroxide in a determined range of polarization. As literature recent showed, carbonaceous materials such as graphite felts or reticulated vitreous carbon have a good efficiency for hydrogen peroxide electrogeneration (Lütz et al. 2004). However, in preliminary studies (data not shown) was also demonstrated a severe increase over adsorption up to $40 \%$ of phenol initial concentration can be expected, as well as over polymeric by-products formed after the enzymatic oxidation, which can difficult further separation operations required during the phenol removal.

Figure 2 shows the voltammograms obtained with copper RDE from aerated and un-aerated buffer phosphate solutions ( $\mathrm{pH}$ 6.0) containing 4-CP. Clearly it can be observed that in the presence of oxygen, the cathodic current increases showing two limited regions (gray-dark line). First region at approximately $-600 \mathrm{mV}_{\mathrm{SCE}}$ corresponds to the hydrogen peroxide production from the cathodic reduction of the dissolved oxygen, and the second region at - $900 \mathrm{mV}_{\mathrm{SCE}}$ corresponds to the formation of water from the reduction of the hydrogen peroxide previously formed. The presence of 4-CP (gray-light line) did not affect the profile observed for the un-aerated solution (black line), this result demonstrates that phenol is not electrochemically active in this polarization rage and did not suffers cathodic reduction.

According to Figure 3, using a copper cathode, the $\mathrm{H}_{2} \mathrm{O}_{2}$ production increases following the decrease of potential up to $-620 \mathrm{mV}_{\mathrm{ECS}}$. The highest hydrogen peroxide generation rates were observed during the first $30 \mathrm{~min}$ of reaction with accumulative maximum concentrations after one hour. After this point, the $\mathrm{H}_{2} \mathrm{O}_{2}$ production decreased, in part due to the use of a discontinuous aeration that limited the oxygen availability, and also from the drop in the oxygen concentration caused by the electrochemical process itself.
The highest hydrogen peroxide generation under these conditions reached $0.77 \mathrm{mmol} \cdot \mathrm{L}^{1}$. But when a continuous air supplementation was applied, hydrogen peroxide concentration increased up to $1.2 \mathrm{mmol} \cdot \mathrm{L}^{-1}$ (Figure 4). Nevertheless, the choice for pre-aeration instead continuous air stripping it was justified in part by the lowest air-drag effect to be caused over the phenolic solution during the process.

\section{Degradation and removal using hydrogen peroxide direct addition (DA)}

Figure 5 shows the enzymatic oxidation of $\mathrm{CP}$ using direct addition of hydrogen peroxide. The maximum degradation levels were observed for $\mathrm{P}$ and 4-CP, when a multiple hydrogen peroxide addition of 5 pulses was used. Lower degradation levels with this addition of 88,66 and $59 \%$ for 2,4-DCP, 2,4,6-TCP and PCP, were observed respectively. Hydrogen peroxide addition also caused chemical oxidation up to $12 \%$ depending on the phenolic compound. This observation corroborates the previous studies where the oxidation of 4-CP was studied (La Rotta and Bon, 2002).

The formation of precipitates was observed during the first 2 hrs. In consequence, $80 \%$ of both $\mathrm{P}$ and $4-\mathrm{CP}$, were removed. In the case of 2,4,6-TCP and PCP only an increase in turbidity was observed with no precipitate formation. Since the simultaneous addition of several coagulants such as chitosan gels was already successfully used with other peroxidases during the enzymatic oxidation of phenols (Zhang et al. 1997; Lai and Lin, 2005), we decided to evaluate its addition in a final concentration of $2 \%(\mathrm{w} / \mathrm{v})$. Consequently, the complete removal of phenol and 4-CP was achieved and increments in removal of 12 and $30 \%$ were observed for 2,4-DCP and 4-CP, respectively. Removal quantification was not possible for 2,4,6-TCP and PCP due in part to their solubility features. However, residual $\mathrm{CP}$ values (data not shown) indicated the incidence of phenol removal from the non polymerized products generated during the enzymatic oxidation and the addition of chitosan.

\section{Bioelectrodegradation of CP}

Figure 6 shows the effect of the cathodic potential over the 4-CP bioelectrochemical degradation. As it can be seen, 4CP bioelectrooxidation at the cathodic chamber (EG CC) increased with the cathodic potential. As a consequence of this, no 4-CP was detected after $4 \mathrm{hrs}$ at $-620 \mathrm{mV}_{\mathrm{SCE}}$. And using -420 and $-220 \mathrm{mV}_{\mathrm{SCE}}, 7$ and $25 \%$ of residual $4-\mathrm{CP}$ was detected, respectively. These results demonstrate the dependence of the applied potential over the electroezymatic degradation. It was also observed anodic direct oxidation (EG $\mathrm{AC}$ ) up to $30 \%$ during the bioelectrochemical processes. Cathodic chamber controls (CC C) with no CPO addition showed $18 \%$ of chemical oxidation due to the electrogenerated hydrogen peroxide. 
In Figure 7 is showed how the hydrogen peroxide electrogeneration plus the enzymatic oxidation of chlorinated phenols, provided excellent oxidation levels after 4 hrs for $\mathrm{P}$ and $4-\mathrm{CP}$, were no residual phenol was detected, and good oxidation levels of $77 \%, 69 \%$ and $59 \%$ for 2,4-DCP, 2,4,6-TCP and PCP, respectively. Additionally, controls for anodic oxidation levels from 10 to $30 \%$ were observed depending on the phenolic compound.

Electrodegradation also droves the precipitation only at the cathodic chamber. As a consequence, when a higher $\mathrm{H}_{2} \mathrm{O}_{2}$ level was produced, the highest precipitate formation occurred. Maximum precipitation was observed for phenol and 4-CP. And only increases in turbidity were observed for 2,4-DCP, 2,4,6-TCP and PCP, with no precipitation. On the other hand, when chitosan was added, removal levels achieved 91,5 and $91,3 \%$, for 4-CP and 2,4-DCP, respectively.

Although the chitosan addition improves removal levels during EG, could also promotes the electrode passivation, since the flocculated product could remains adhered on the electrode, promoting mass transfer problems and decreasing the electrode life-time. This result shows that application use of chistosan or other coagulants during EG should be analysed, probably in a discontinuous processes or with a different reactor arrangement.

As showed in Table 1, initial oxidation rates were higher for DA than EG. As such, an increment of two fold-times was observed when DA was used during the oxidation of 4CP. In the case of PCP and 2,4-DCP increments of 4 and 6 fold-times, were respectively observed. For TCP, the lowest initial oxidation rate was achieved. This observation can be related to the hydrogen peroxide availability at the reaction medium, especially for EG where an effective hydrogen peroxide concentration is very small and depends on the dissolved oxygen concentration.

Aiming to improve the bioelectrooxidation process in terms of efficiency and reaction rates, experiments of electrochemical generation of hydrogen peroxide and simultaneous enzymatic oxidation of $\mathrm{CP}$ were evaluated in a single chamber reactor with continuous aeration. As it can be seen in Figure 8 same oxidation levels were obtained for $\mathrm{P}$ and $4-\mathrm{CP}$. Improvements up to $97 \%, 93 \%$ and $88 \%$ for 2,4-DCP, 2,4,6-TCP and PCP, were observed respectively. As it can also be observed in Table 1, reaction rates obtained using EG in a single chamber reactor showed to be quite similar to those obtained using a 5-pulsated addition of hydrogen peroxide.

\section{Evaluation of residual peroxidase activity}

This parameter indicated the real advantages between EG and DA in terms of enzyme stability. Figure 9 shows the residual peroxidase activity observed after $4 \mathrm{hrs}$ in experiments using single and a 5-pulsated direct addition
(DA) of hydrogen peroxide. Also, the electrogeneration (EG) in a single-chamber reactor was compared with a control with no $\mathrm{CPO}$ addition.

Although, both methodologies were similarly efficient in terms of phenol oxidation and precipitate formation, it was observed that CPO loses activity rapidly when the direct addition was employed. This fact is not just related to the presence of hydrogen peroxide, but is even more remarkable when both oxidized products and hydrogen peroxide were simultaneously present during the reaction with DA or EG, indicating a possible suicide inactivation already observed for oxidases such as tyrosinase (Haghbeen et al. 2004). Thus, up to $60 \%$ of initial activity was lost in DA experiments, followed by $40 \%$ using EG after $4 \mathrm{hrs}$. Free and pure $\mathrm{CPO}$ in 100 mmoles $\cdot \mathrm{L}^{-1}$ potassium phosphate buffer $\mathrm{pH} 6.0$ remained stable up-to $4 \mathrm{hrs}$ at $25^{\circ} \mathrm{C}$. In terms of inactivation rates (Table 2), CPO was more rapidly inactivated with the direct addition of hydrogen peroxide rather than with its electrogeneration. On the other hand, $\mathrm{CPO}$ presented half-life and work-life times two fold-times higher when EG were used instead DA.

\section{CONCLUDING REMARKS}

The continuous EG and pulsated DA of the hydrogen peroxide offer the possibility to conciliate effective an hydrogen peroxide availability to undisruptive concentrations in the reaction mixtures containing phenol, 4-CP, 2,4-DCPl, 2,4,6-TCP and PCP, selected as targets for enzymatic oxidation in batch reactions using chloroperoxidase. With EG system it was possible to obtain variable hydrogen peroxide concentrations depending on the working electrode material, the applied cathodic potential and aeration mode. Working electrode materials of graphite felt, reticulate vitreous carbon foam and an electrolytic copper web were evaluated, in terms of hydrogen peroxide generation, efficiency and phenol adsorption. All materials showed excellent results in terms hydrogen peroxide electrogeneration, however the carbonaceous materials showed the highest phenol adsorption. When a bicompartmented cell was used, bioelectrooxidation of the $\mathrm{CP}$ was comparable to the conventional enzymatic oxidation of $\mathrm{CP}$ using direct addition. In both cases a low chemical oxidation due to the hydrogen peroxide was observed. On the other hand, when EG was performed in a single-chamber reactor a better accumulative effect of chemical, anodic and enzymatic oxidations of CP was attained. DA and EG systems also led $\mathrm{CP}$ removal by the precipitation derived from the polymerization of these phenolic compounds. The use of coagulant agents was advantageous in both cases. Even thought, DA was relatively more efficient in terms of enzymatic oxidation than the electrochemical approach, this last one showed a lower inactivation rates, and longer halflife and work-life times. 


\section{REFERENCES}

ANNACHATRE, A.P. and GHEEWALA, S.H. Biodegradation of chlorinated phenolic compounds. Biotechnology Advances, 1996, vol. 14, no. 1, p. 35-56.

ATLOW, Stuart C.; BONADONNA-APARO, Lucia and; KLIBANOV, Alexander M. Dephenolization of industrial wastewaters catalyzed by polyphenol oxidase. Biotechnology and Bioengineering, June 1984, vol. 26, no. 6, p. 599-603.

BABOROVÁ, Petra; MÖDER, Monika; BALDRIAN, Petr; CAJTHAMLOVÁ, Kamila and CAJTHAML, Tomas. Purification of a new manganese peroxidase of the whiterot fungus Irpex lacteus, and degradation of polycyclic aromatic hydrocarbons by the enzyme. Research in Microbiology, April 2006, vol. 157, no. 3, p. 248-253.

CARMICHAEL, Robert; FEDORAK, Phillip M. and PICKARD, Michael A. Oxidation of phenols by chloroperoxidase. Biotechnology Letters, April 1985, vol. 7, no. 4, p. 289-294.

CHEN, J.K. and NOBE, K. Oxidation of dimethylaniline by horseradish peroxidase and electrogenerated peroxide: I. Free enzyme Studies. Journal of the Electrochemical Society, February 1993, vol. 140, no. 2, p. 299-303.

DENIZLI, Adil; CIHANGIR, Nilüfer; YOUSEFI RAD, Abbas; TANER, Müge and ALSANCAK, Güleren. Removal of chlorophenols from synthetic solutions using Phanerochaete chrysosporium. Process Biochemistry, October 2004, vol. 39, no. 12, p. 2025-2030.

EIBES, Gemma; CAJTHAML, Thomas; MOREIRA, Maria Teresa; FEIJOO, Gumersindo and LEMA, Juan M. Enzymatic degradation of anthracene, dibenzothiophene and pyrene by manganese peroxidase in media containing acetone. Chemosphere, June 2006, vol. 64, no. 3, p. 408414.

FERREIRA-LEITAO, Viridiana S.; BON, Elba P.S. and DA SILVA, Jose Godinho. Methylene blue and azure B oxidation by horseradish peroxidase: a comparative evaluation of class II and class III peroxidases. Applied Catalysis B: Environmental, May 2003, vol. 42, no. 2, p. 213-221.

FIAMEGOS, Y.; STALIKAS, C. and PILIDIS, G. 4Aminoantipyrine spectrophotometric method of phenol analysis - Study of the reaction products via liquid chromatography with diode-array and mass spectrometric detection. Analytica Chimica Acta, September 2002, vol. 467, no. 1, p. 105-114.

HAGHBEEN, Kamahldin; SABOURY, Ali Akbar and KARBASSI, Farhad. Substrate share in the suicide inactivation of mushroom tyrosinase. Biochimica et
Biophysica Acta (BBA) - General Subjects, November 2004, vol. 1675, no. 1-3, p. 139-146.

KIM, G.-Y. and MOON, S.-H. Degradation of pentachlorophenol by an electroenzymatic method using immobilized peroxidase enzyme. Korean Journal of Chemical Engineering, January 2005, vol. 22, no. 1, p. 5260.

LA ROTTA, Camilo E. and BON, Elba P.S. 4Chlorophenol degradation by chloroperoxidase from Caldariomyces fumago formation of insoluble products. Applied Biochemistry and Biotechnology, March 2002, vol. 98, no. 1-3, p. 191-204.

LA ROTTA, Camilo E.; LUTZ, Stephan; LIESE, Andreas and BON, Elba P.S. Activity and stability of Caldariomyces fumago chloroperoxidase modified by reductive alkylation, amidation and cross-linking. Enzyme and Microbial Technology, November 2005, vol. 37, no. 6, p. $582-588$.

LAI, Yi-Chen and LIN, Sung-Chyr. Application of immobilized horseradish peroxidase for the removal of $p$ chlorophenol from aqueous solution. Process Biochemistry, March 2005, vol. 40, no. 3-4, p. 1167-1174.

LAURENTI, Enzo; GHIBAUDI, Elena; ARDISSONE, Silvia and FERRARI, Rosa Pia. Oxidation of 2,4dichlorophenol catalyzed by horseradish peroxidase: characterization of the reaction mechanism by UV-visible spectroscopy and mass spectrometry. Journal of Inorganic Biochemistry, June 2003, vol. 95, no. 2-3, p. 171-176.

LÜTZ, Stephan; STECKHAN, Eberhard and LIESE, Andreas. First asymmetric electroenzymatic oxidation catalyzed by a peroxidase. Electrochemistry Communications, June 2004, vol. 6, no. 6, p. 583-587.

METELITZA, Dimitriy I.; LITVINCHUK, Alenxandra V. and SAVENKOVA, Marina L. Peroxidase-catalysed cooxidation of halogen-substituted phenols and 4aminoantipyrine. Journal of Molecular Catalysis, August 1991, vol. 67 , no. 3, p. 401-411

MORRIS, David R. and HAGER, Lowell P. Chloroperoxidase. I. Isolation and properties of the crystalline glycoprotein. Journal of Biological Chemistry, April 1966, vol. 241, no. 8, p. 1763-1768.

NICELL, J.A.; BEWTRA, J.K.; BISWAS, N. and TAYLOR, E. Reactor development for peroxidases catalyzed polymerization and precipitation of phenols from wastewater. Water Research, November 1993, vol. 27, no. 11, p. 1629-1639.

NICELL, James A. and WRIGHT, Harold. A model of peroxidase activity with inhibition by hydrogen peroxide. Enzyme and Microbial Technology, September 1997, vol. 21 , no. 4 , p. 302-310. 
RIVAS, Javier F.; KOLACZKOWSKI, Stan T.; BELTRAN, Fernando J. and MCLURGH, David B. Hydrogen peroxide promoted wet air oxidation of phenol: influence of operating conditions and homogeneous metal catalysts. Journal of Chemical Technology and Biotechnology, May 1999, vol. 74, no. 5, p. 390-398.

VASUDEVAN, P.T. and LI, L.O. Peroxidase catalyzed polymerization of phenol. Applied Biochemistry and Biotechnology, 1996, vol. 60, no. 1, p. 73-82.

WAGNER, Monika and NICELL, James A. Detoxification of phenolic solutions with horseradish peroxidase and hydrogen peroxide. Water Research, September 2002, vol. 36 , no. 16 , p. 4041-4052.

YEE, Dennis C. and WOOD, Thomas K. 2,4Dichlorophenol degradation using Streptomyces viridosporus T7A lignin peroxidase. Biotechnology Progress, February 1997, vol. 13, no. 1, p. 53-59.

ZHANG, Guoping and NICELL, James A. Treatment of aqueous pentachlorophenol by horseradish peroxidases and hydrogen peroxide. Water Research, April 2000, vol. 34, no. 5 , p. 1629-1637.

ZHANG, tong; ZHAO, Qingxiang; HUANG, Hui; II, Qin and ZHANG, Yi. Removal of toxic phenol and 4chlorophenol from waste water by horseradish peroxidases. Chemosphere, February 1997, vol. 34, no. 4, p. 893-913. 


\section{APPENDIX}

TABLES

Table 1. Comparison between the effects of DA in pulsed addition up-to $5 \mathrm{X}$ and electrogeneration of hydrogen peroxide in bicompartmented cell and single-chamber reactor over the initial oxidation rates of CP.

\begin{tabular}{|c|c|c|c|c|c|}
\hline & $\begin{array}{c}1 \mathrm{x} \\
\mathrm{Vo} \\
\mu \mathrm{M} \mathrm{mL^{-1 }} \mathrm{min}^{-1}\end{array}$ & $\begin{array}{c}5 x \\
\text { Vo } \\
1 \\
\mu M \mathrm{~mL}^{-1} \min ^{-1}\end{array}$ & $\begin{array}{c}\text { EG } \\
\text { (Bicomp.) } \\
\text { Vo } \\
\mu \mathrm{M} \mathrm{mL}^{-1} \mathrm{~min}^{-1}\end{array}$ & $\begin{array}{c}\text { EG } \\
\text { (Single chamber) } \\
\text { Vo } \\
\mu \mathrm{M} \mathrm{mL}^{-1} \mathrm{~min}^{-1}\end{array}$ & $\begin{array}{c}\text { Increment } \\
\text { Bicomp. vs } \\
\text { Single chamber \% }\end{array}$ \\
\hline $\mathbf{P}$ & 0.00961 & 0.00980 & 0.00790 & 0.00920 & 14,1 \\
\hline 4-CP & 0.01063 & 0.01300 & 0.00710 & 0.00820 & 13,4 \\
\hline 2,4-DCP & 0.00783 & 0.01350 & 0.00240 & 0.00740 & 67,5 \\
\hline 2,4,6-TCP & 0.00431 & 0.00580 & 0.00060 & 0.00420 & 85,7 \\
\hline PCP & 0.00243 & 0.00410 & 0.00110 & 0.00390 & 71,8 \\
\hline
\end{tabular}

Table 2. Inactivation rates for CPO using DA by single and $5 \mathrm{X}$ pulsed additions and electrogeneration (EG) of hydrogen peroxide. Half-life time (HLT) and work-life time (WLT) for CPO were estimated in all cases.

\begin{tabular}{|l|c|c|c|}
\hline & $\begin{array}{c}\mathbf{k}_{\text {inact }} \\
\text { UI } \mathbf{~ m L}^{-1} \mathbf{m i n}^{-1}\end{array}$ & $\begin{array}{c}\text { WLT } \\
\mathbf{h}\end{array}$ & $\begin{array}{c}\text { HLT } \\
\mathbf{h}\end{array}$ \\
\hline EG & 0.0092 & 11.2 & 5.7 \\
\hline DA 1X & 0.0162 & 6.2 & 3.1 \\
\hline DA 5X & 0.0146 & 6.9 & 3.5 \\
\hline CPO & 0.0001 & 998.0 & 498.0 \\
\hline
\end{tabular}




\section{FIGURES}

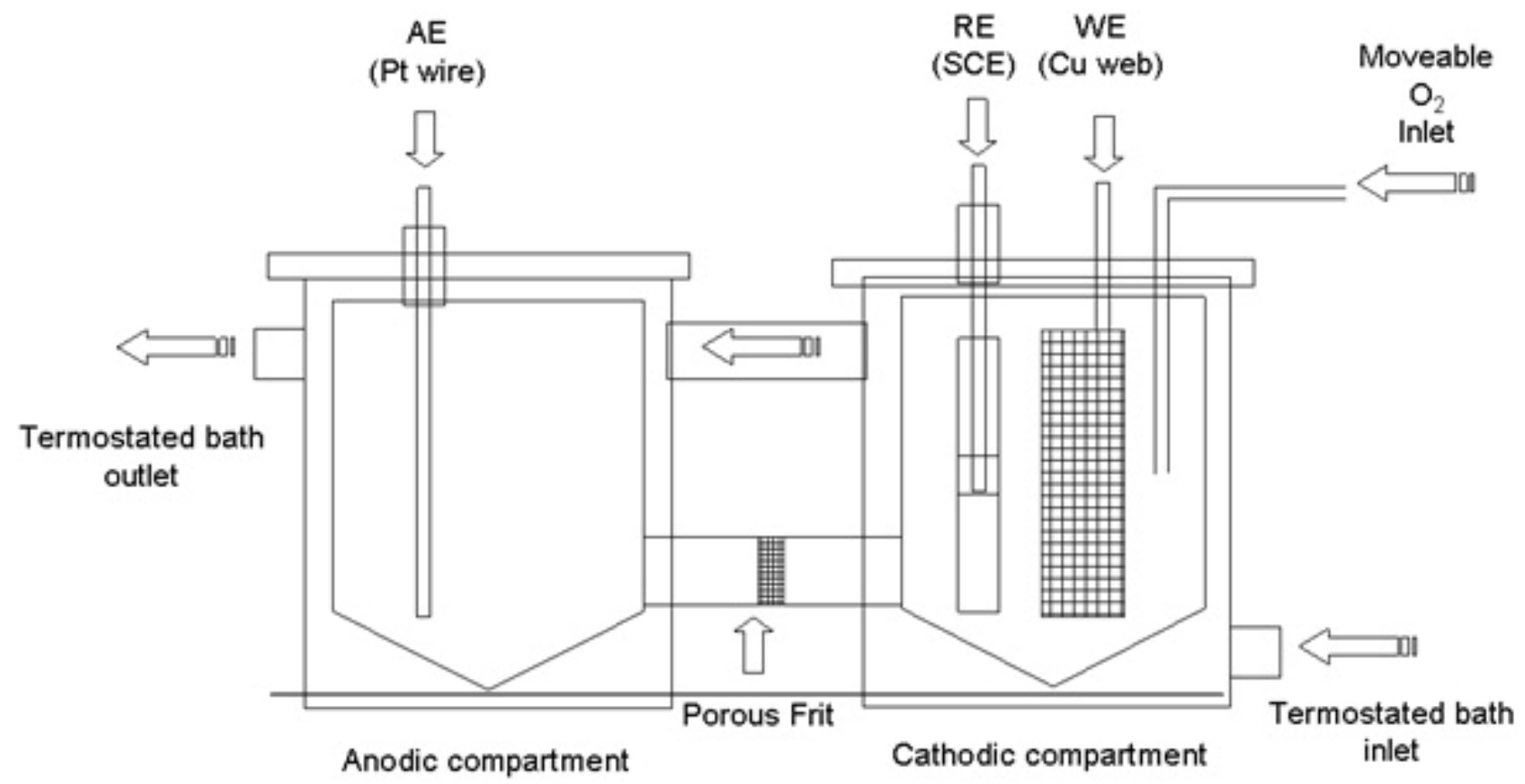

Figure 1. Diagram for the bicompartmented electrochemical cell used during the experiments for hydrogen peroxide generation and bioelectrochemical oxidation of chlorinated phenols. AE: auxiliary electrode; RE: reference electrode; We: working electrode.

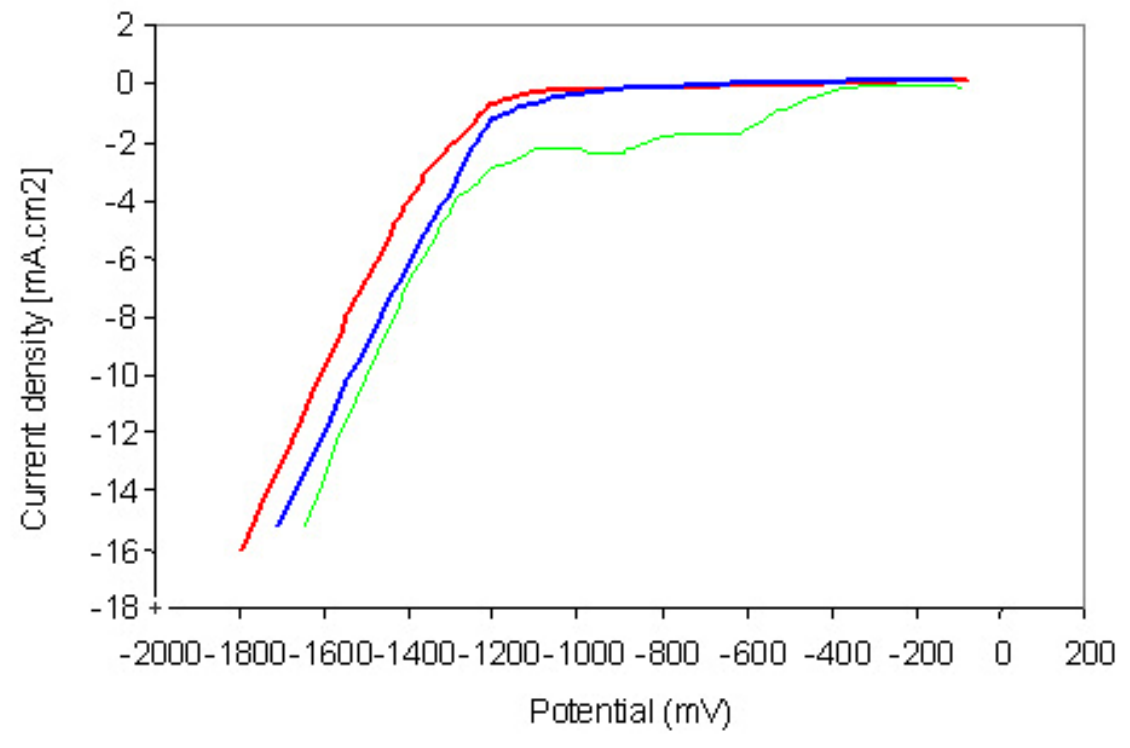

- un-aerated 4 -CP solution a un-aerated solution a aerated solution

Figure 2. Voltammetry profiles for copper RDE $\left(0.2 \mathrm{~cm}^{2}\right)$ obtained at $1000 \mathrm{rpm}$ using in $100 \mathrm{mmol} \cdot \mathrm{L}^{-1} \mathrm{sodium}-\mathrm{potassium}$ phosphate buffer $\mathrm{pH} 6.0$ at $25^{\circ} \mathrm{C}$ with a $150 \mathrm{mV} \cdot \mathrm{s}^{-1}$ scan rate. 
La Rotta, C.E. et al.

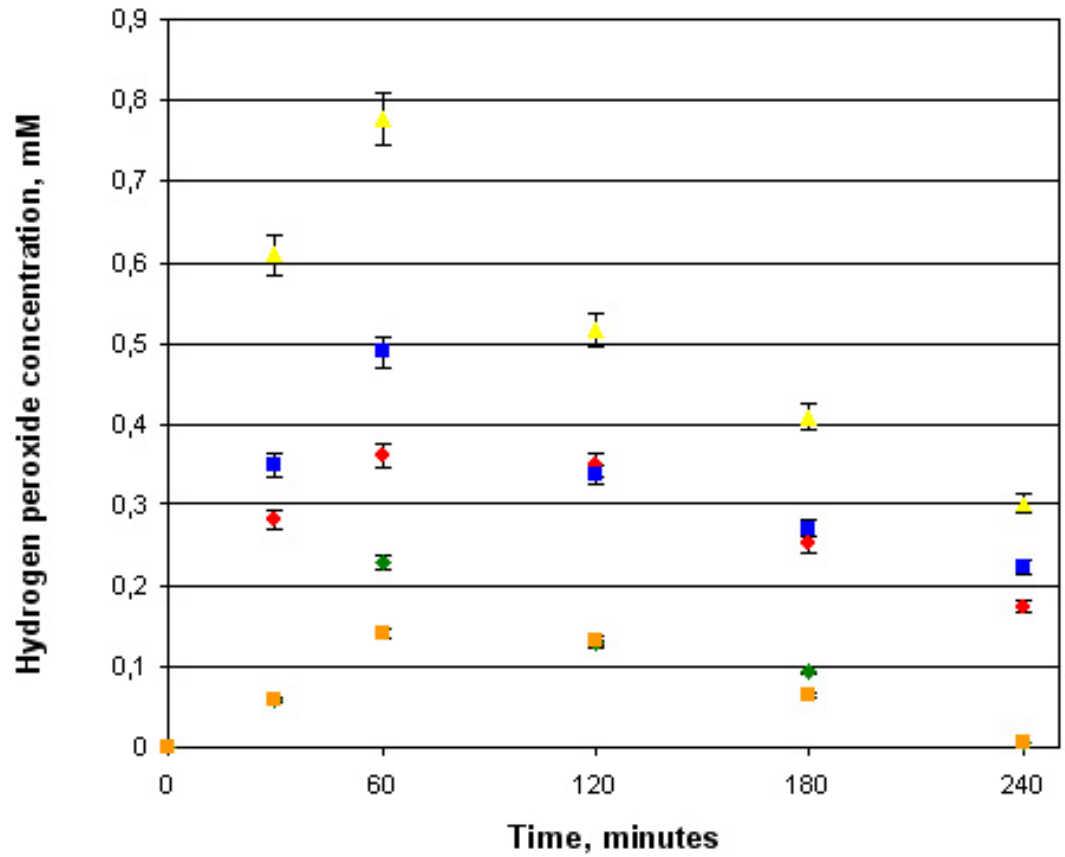

$\bullet-220 \square-420 \quad-620 \bullet-720 \backsim-820$

Figure 3. Effect of the applied potentials over the hydrogen peroxide electrogeneration. Bicompartmented cell using an electrolytic copper web of $27 \mathrm{~cm}^{2}(\mathrm{WE})$; pre-aeration of $1 \mathrm{hr}\left(\mathrm{O}_{2} 0.5 \mathrm{vvm}\right)$, in $100 \mathrm{mmol} \cdot \mathrm{L}^{-1}$ sodium-potassium phosphate buffer $\mathrm{pH} 6.0$, at $25^{\circ} \mathrm{C}$.

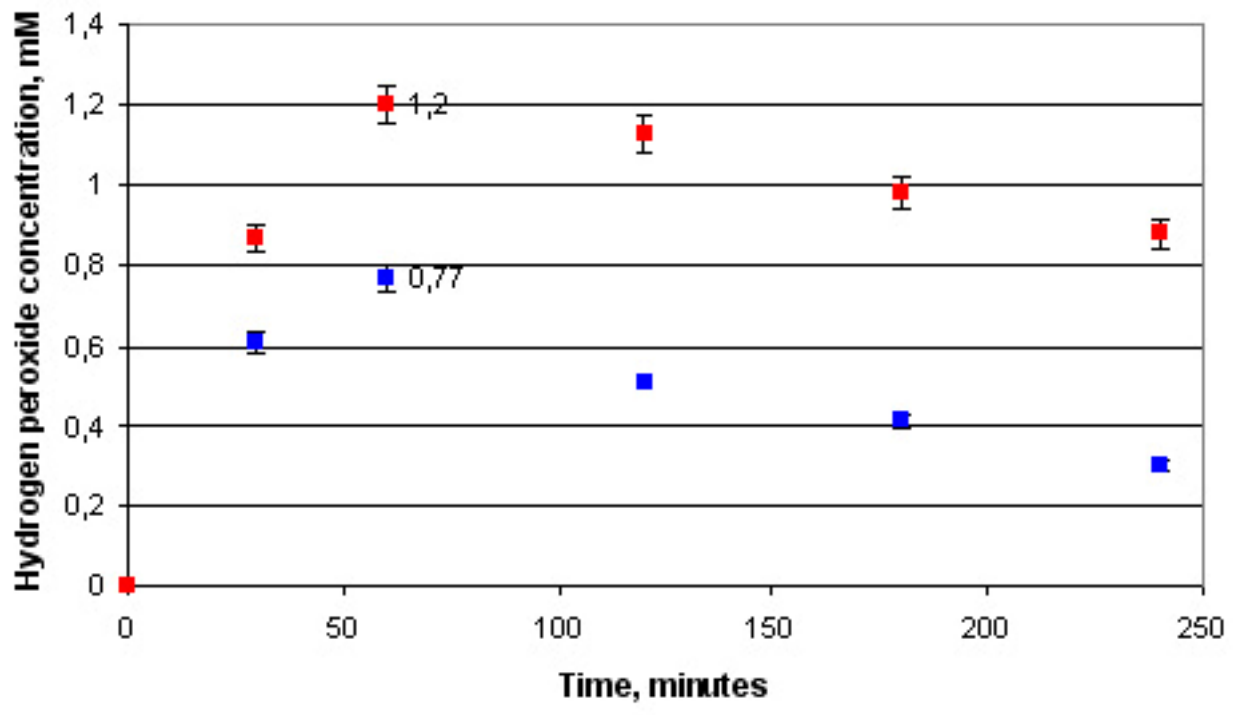

$\mathrm{AD}=\mathrm{AC}$

Figure 4. Effect of the aeration mode over the hydrogen peroxide electrogeneration. Pre-aeration $\left(\mathrm{O}_{2} 0.5 \mathrm{vvm}\right)$ of $1 \mathrm{hr}(\mathbf{m})$; and continuous aeration $\left(\mathrm{O}_{2} 0.5 \mathrm{vvm}\right)$, during $4 \mathrm{hrs}(\square)$. In a $100 \mathrm{mmol} \cdot \mathrm{L}^{-1}$ sodium-potassium phosphate buffer $\mathrm{pH} 6.0$ at $25^{\circ} \mathrm{C}$ 


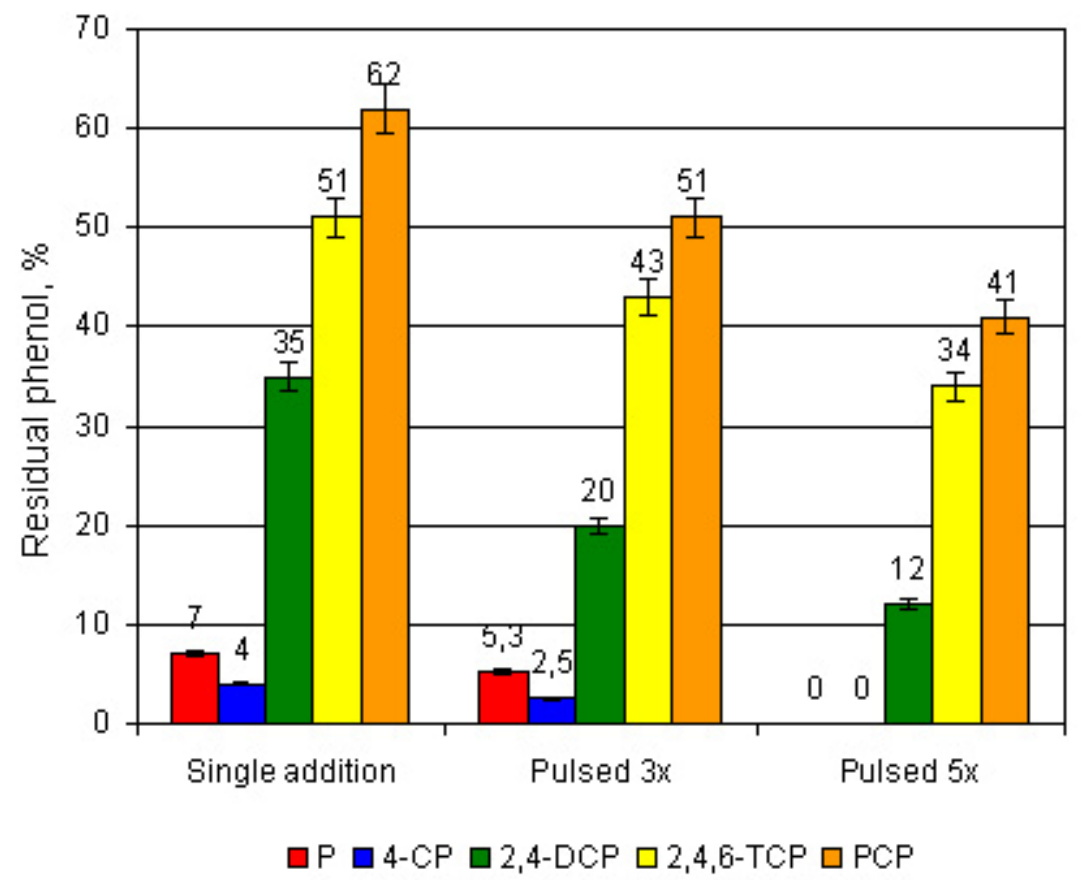

Figure 5. Effect of hydrogen peroxide direct addition: single addition, pulsed three and five additions, over the enzymatic oxidation of chlorinated phenols by CPO.

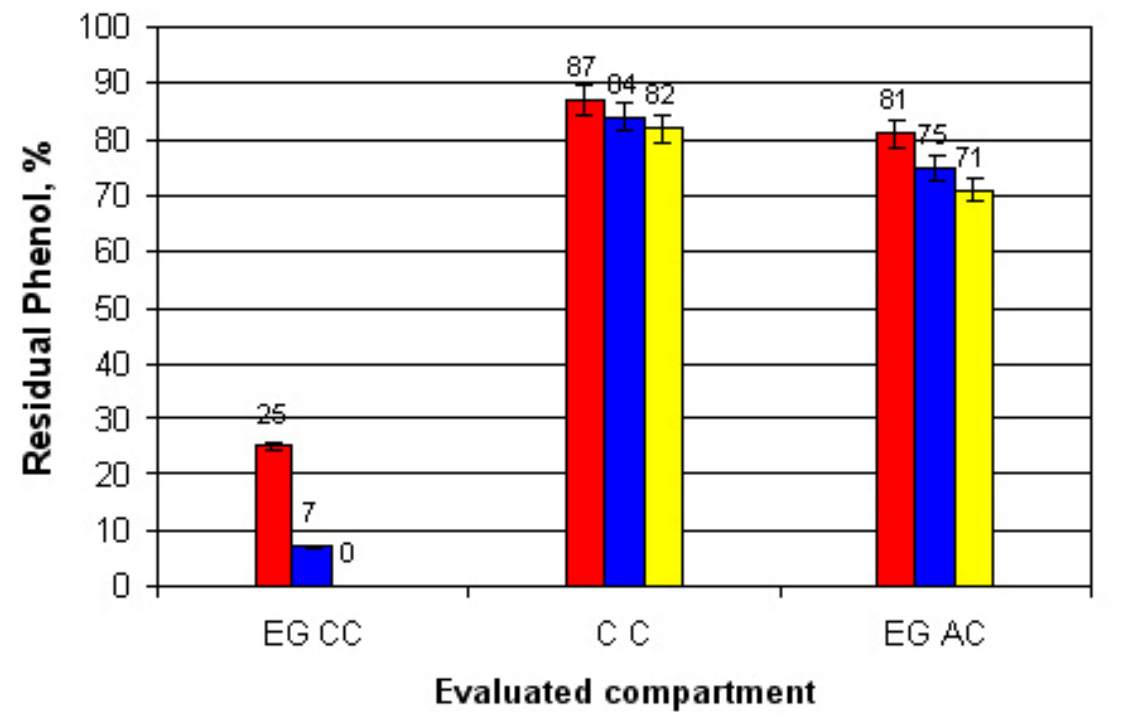

$\square-220 \square-420 \square-620$

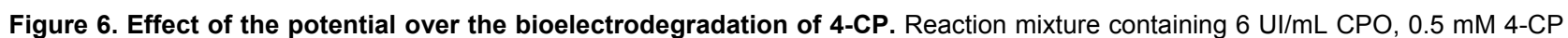
in $100 \mathrm{mM}$ sodium-potassium phosphate buffer $\mathrm{pH} 6.0$, at $25^{\circ} \mathrm{C}$. EG CC: bioelectrodegradation at the cathodic chamber; EG AC: Anodic oxidation in the anodic chamber; CC C: Cathodic chamber control. 
La Rotta, C.E. et al.

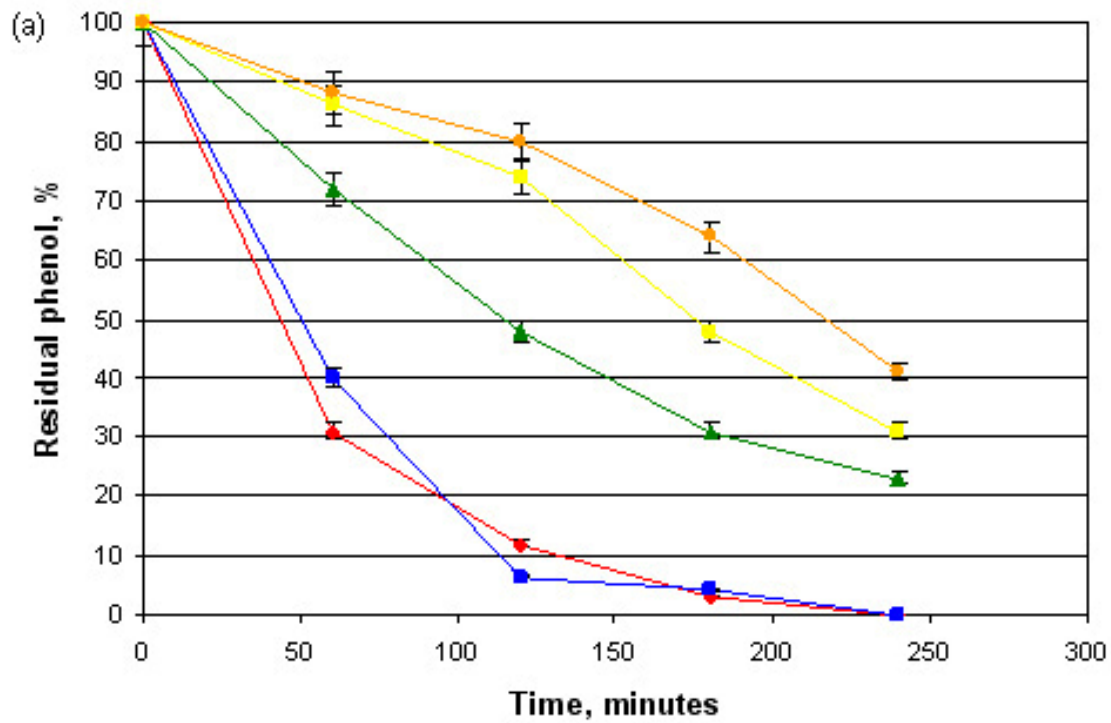

e, minutes

$\leftrightarrow \mathrm{P} \rightarrow-4-\mathrm{CP} \longrightarrow 2,4-\mathrm{DCP}=2,4,6-\mathrm{TCP} \longrightarrow \mathrm{PCP}$

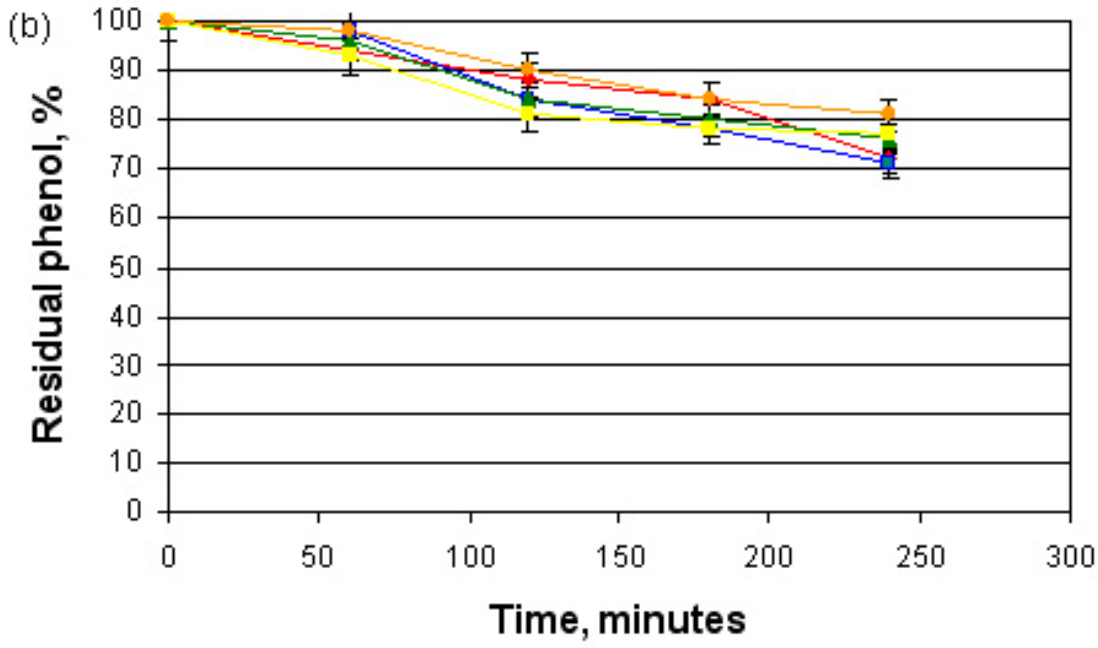

$\rightarrow \mathrm{P} \rightarrow-4-\mathrm{CP} \rightarrow 2,4-\mathrm{DCP}=2,4,6-\mathrm{TCP} \rightarrow \mathrm{PCP}$

Figure 7. Bioelectrodegradation of CP during the electrolysis at $-620 \mathrm{mV}$ in:

(a) Cathodic chamber EG CC.

(b) Anodic chamber using discontinuous pre-aeration of $1 \mathrm{hr}$. 


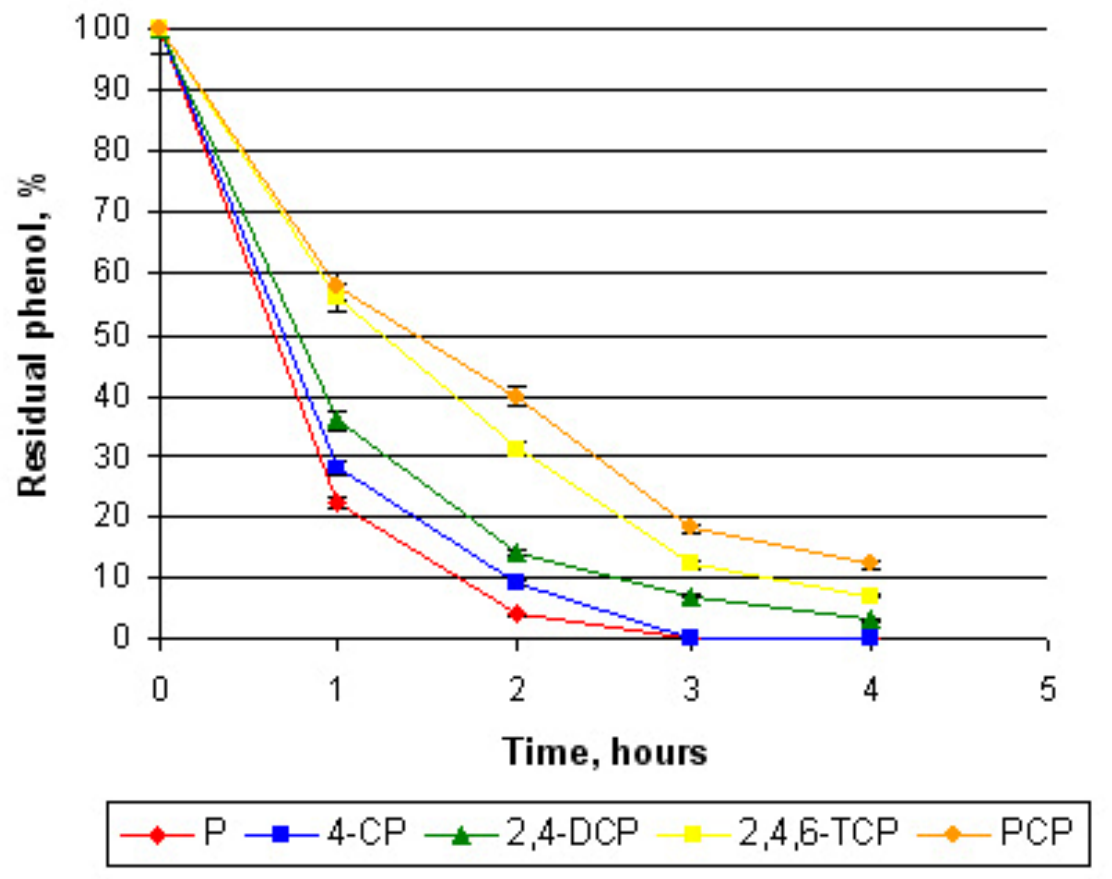

Figure 8. Bioelectrodegradation of $\mathrm{CP}$ during the electrolysis at $-620 \mathrm{mV}$ in single camber reactor. Using continuous aeration during $4 \mathrm{hrs}\left(\mathrm{O}_{2} 0.5 \mathrm{vvm}\right)$. Reaction mixtures containing $6.0 \mathrm{UI} / \mathrm{mL}$ of $\mathrm{CPO}, 0.5 \mathrm{mM}$ of CP in $100 \mathrm{mM}$ sodium-potassium phosphate buffer $\mathrm{pH} 6.0$ at $25^{\circ} \mathrm{C}$ and $200 \mathrm{rpm}$.

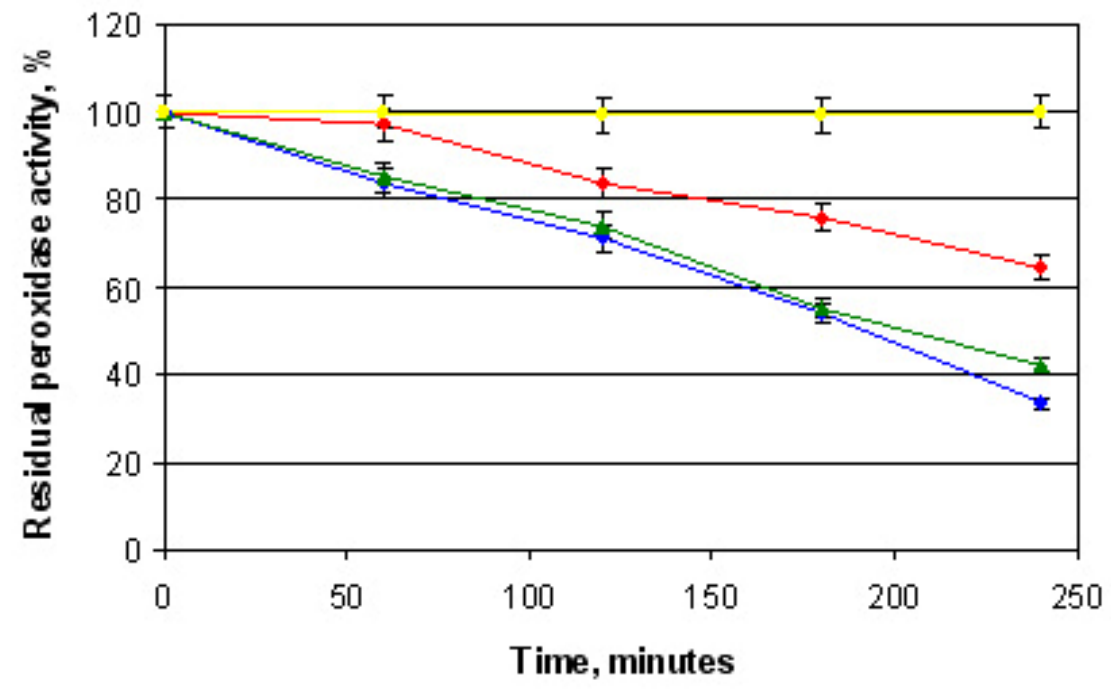

$\rightarrow-E G \rightarrow$ DA $1 X \rightarrow$ DA $5 X \multimap$ Control

Figure 9. Comparison of CPO residual activities during 4 hrs using direct addition (DA by single and 5X pulsed additions, bioelectrochemical (EG) process with continuous aeration (EG $-620 \mathrm{mV}_{\mathrm{SCE}}$ ) and controls with only CPO. Reaction mixtures contained $6.0 \mathrm{UI} / \mathrm{mL}$ CPO, $0.5 \mathrm{mM} \mathrm{CP}, 1.0 \mathrm{mM}$ peroxide concentration for DA in $100 \mathrm{mM}$ sodium-potassium phosphate buffer pH 6.0 at $25^{\circ} \mathrm{C}$ and $200 \mathrm{rpm}$. 